more than ten hours but apart from the monotony of the eight hours of maintenance the average patient does not complain. Patients ill with arthritis need to be nursed very carefully but derive immediate relief from the warmth of the cabinet. They are particularly comfortable during treatment and in most cases this could continue for many more hours. Women are admirable patients, and age does not seem to contra-indicate the treatment. It is arranged that the entire treatment of any patient is carried out by the same nurse who is relieved for short periods only for meals. A patient is never left alone for one moment during the whole course of the treatment nor for several hours afterwards.

\title{
Essentials of nursing
}

It will be seen that the nursing hours are long and that the work is arduous. This branch of nursing although limited in scope is extremely interesting and needs the qualities of placidity, good temper and conscientiousness in the nurse. A medical officer although not present continuously throughout treatment remains within call both day and night and the nursing staff can always communicate with him for immediate advice and instruction.

Acknowledgment is made to Col. G. P. Kidd, M.C., R.A.M.C., Officer Commanding, and to Miss C. R. Hammond, R.R.C., Q.A.I.M.N.S., Matron, for permission to publish this paper.

\section{VENEREAL DISEASE IN PEPYS'S DIARY *}

\author{
By J. D. ROLLESTON, M.D., F.R.C.P., F.S.A.
}

The medical aspects of Pepys's Diary have been discussed by many writers within the last fifty years, as a glance at the second and third series of the SurgeonGeneral's Catalogue (S. V. Pepys) will show. Considerable attention has been given to the subject by the late Sir D'Arcy Power, who has specially dealt with Pepys's ocular and urinary troubles, as well as with his minor illnesses and his wife's ailments. Other medical articles on Pepys are those by Sir William MacArthur, Mr. R. R. James, Dr. C. MacLaurin and Mr. William Jones. No work, however, to my knowledge, has been devoted to the mention of venereal diseases in the Diary.

As I have recently dealt with the occurrence of syphilis among the courtiers of Louis XIV and the Regency as described by Saint-Simon's Mémoires which covered the period 1693-1723, it occurred to me that I might make a similar study of Pepys's Diary which was ranged with the years 1659-69.

The lack of any previous article on the subject seems to be owing to the fact that until the publication of H. B. Wheatley's edition (1893-9) the Diary underwent extensive expurgation before it appeared, all the passages relating to venereal disease being suppressed. The Diary has gone through six successive editions, the first four under the supervision of Lord Braybrooke being published in 1825, $1828,1848-9$ and 1854 and the fifth being edited by Wheatley. In the first edition barely half of Pepys's manuscript was printed, but as the result of protests more passages were added to each of the subsequent editions. Wheatley's edition, which first appeared in 1893-9, although containing a large proportion of the passages suppressed by Braybrooke, still had a number of omissions which Wheatley declared "could not possibly be printed." Wheatley, however, unlike Braybrooke, whenever a passage was suppressed, inserted marks of omission, so that, as he says, " in all cases readers will know where anything has been left out." In the capacity of chercheur et curieux I have counted up the omissions in the Wheatley edition, and found that they amount to eighty-four. Fifty-five of these, judging from the context, are erotic in character or deal with venereal disease, twenty-two are concerned with non-erotic urinary troubles, and seven give no indication of the cause of the omission.

* The edition of the Diary quoted in this paper is that edited by H. B. Wheatley in 8 volumes, 1919. 


\section{THE BRITISH JOURNAL OF VENEREAL DISEASES}

Victorian prudery, from the results of which the Diary had to suffer so grievously, was not confined to the laity. In a footnote to an admirable article by. Sir D'Arcy Power read before the Abernethian Society at St. Bartholomew's Hospital on 6th March, 1895, and published in the Lancet the following 1st June under the title " The Medical History of Mr: and Mrs. Pepys," the editor remarks, "It is right to say that we have omitted some of the quotations from the Diary, Mr. Pepys's language being occasionally too blunt and outspoken even in a medical journal." It was not until 1917 that an unexpurgated version of the paper appeared in the Occasional Papers of the Samuel Pepys Club. The delay in the appearance of the final and complete edition, a delay which Pepys scholars must regard as one of "the minor horrors of war," will, it is to be hoped, end soon after the termination of hostilities. I am indebted to Mr. A. B. Ramsay, Master of Magdalene College, Cambridge where in peace-time the MS of the Diary is preserved, for informing me that when the new edition appears fifty copies will first be privately printed with no omissions and will be presented to the leading libraries, and then the remaining copies will be published with a few omissions.

In view of the frequency of his extraconjugal relations the question naturally arises whether Pepys himself was not affected by Some venereal disease. The question cannot be satisfactorily answered until the appearance of an unexpurgated edition of the Diary, In the meantime there is no evidence in his writings, which besides the first or chief Diary contain the second or Tangier Diary (1683-4) as well as, the voluminous collection of letters edited by Tanner, that he contracted any venereal disease.

His chief troubles were his eye condition which Sir D'Arcy attributed to presbyopia with astigmatism, and stone in the bladder, for which he underwent lateral lithotomy on 26th March, 1658, at the age of twenty-five and from which he suffered relapses throughout the rest of his life, a small nest of seven stones being found in his kidney post mortem (MacLaurin, 1930). Pepys's other illnesses, as Sir D'Arcy points out, were of a minor character and were neither numerous nor interesting, merely consisting in severe attacks of indigestion for which alcoholic excess was often responsible, haemorrhoids and boils.

The severe abdominal pain from which his wife frequently suffered, and of which Pepys himself gives a very obscure account, is attributed by Sir D'Arcy.(1895) to a vulvar abscess or to an ischio-rectal abscess pointing a little more anteriorly than usual and terminating in a fistula. The possibility of a vulvar abscess being due to infection on the part of her husband is not supported by anything in the Diary, and Sir D'Arcy attributes the sterility of the marriage to lesions of the ejaculatory ducts infected during Pepys's operation of lateral lithotomy for stone in the bladder.

Dr. MacLaurin (1921) attributes Pepys's immunity to venereal diseases to their not being so frequent in the England of the Restoration as they are today, but there does not appear to be any evidence of this hypothesis in view of the numerous cases mentioned by Pepys. Moreover, as Havelock Ellis (1910) points out, Pepys's partners were rarely prostitutes but were mostly women of a low social class, such as shop assistants, workmen's wives and superior servant girls. Pepys, unlike Casanova as I have shown in a previous article (1917), was not a sexual athlete, and many of his erotic bouts, as Havelock Ellis remarks, were little more than trivial liberties.

Mr. William Jones, the Librarian of the Liverpool Medical Institute, has suggested that an enlarged prostate gland was the cause of Pepys's numerous amatory adventures, but that this was the case is unlikely in view of the fact that during the period of the chief Diary in 1658-1669 Pepys was under forty, while the Tangier Diary, in which there is no reference to erotic exploits, was written when Pepys was over fifty. His alcoholic excesses, to which he often alludes and against which he frequently made a vow which he seldom kept, may account to some extent for his erotic indulgence, especially as many of his exploits took place in ale-houses. 
The only words used in the Diary to denote venereal disease are " clap " and " pox." The term "syphilis," although first introduced by Fracastor in 1542, for a long time did not receive general recognition and, according to Jeanselme (1931) during the whole of the seventeenth and eighteenth centuries only about half a dozen writers used it. Moreover, as I have shown in a previous paper in the Journal (1934), the terms "clap" and "pox" were often used indiscriminately, the word "pox" being sometimes applied to gonorrhoea, while the term "clap" meant syphilis. It must also be borne in mind that " pox" was sometimes regarded not as an independent disease but as the last stage of " clap," as is shown by Pope's well-known line "Time that at last matures a clap to pox." In these circumstances, in the absence of characteristic symptoms or sequelae such as ardor urinae in the case of gonorrhoea or necrosis of the nasal bones in the case of syphilis, it is almost impossible to tell what is meant by the colloquial terms "clap" and " pox."

Although chancroid is probably as old as gonorrhoea, which in its turn is "as old as the world" (Luys, 1921) the absence in the Diary of a description of this local lesion makes it impossible to determine the nature of the sore, and the same applies to the other forms of venereal disease, so that venereal disease in the Diary must be regarded as indicating syphilis or gonorrhoea only.

The high incidence of venereal disease in London at the time of the Restoration among all classes of society; and particularly the Court, is shown in the following passages in the Diary. " Pickering tells me plainly of the vices of the Court and how the pox is so common there, and so I hear on all hands that it is as common as eating and swearing "' (II, 89). One of the chief favourites of Charles II was Sir Alexander Frazier, of whom Pierce, a surgeon who was an intimate friend of Pepys, says " he is so great with my Lady Castlemayne and all the ladies at Court in helping them slip their calfes when there is occasion and the great men in curing of their claps, that he can do what he pleases with them " (IV, 230). The association of criminal abortion indicated by the words, "helping them to slip their calfes," is also indicated by the following conversation of Pepys and the surgeon Pierce in Whitehall. "Mr. Pierce, I asking him whither he was going, told me as a great secret that he was going to his master's mistress . . . (one of the maids of honour to the Duchess of York) with some physic, meaning for the pox I suppose or else that she is got with child" (VIII, 186). How readily a mistaken diagnosis of venereal disease was made is exemplified by the case of Pepys's brother Tom, who was regarded by a Mr. Powell as suffering from pox, but was found by Dr. Wiverley to be entirely free from the disease (IV, 67).

The most notable individual case of venereal disease, which was undoubtedly one of syphilitic necrosis of the skull, was that of the gallant Prince Rupert, described on 15th January, 1664-5 by Pepys as follows (IV, 311) : " My Lord FitzHarding come thither and made nothing to say that the disease was the pox and that he must be fluxed, telling the horrible degree of the disease upon him with its breaking out upon him. Since we told him that we believe that he would overcome his disease, he is as merry and laughs and curses and do all the things of a (man) in health, as ever he did in his life." About two years later (VI, 143) (28th January, 1666-7) Pepys hears from Mr. Hayes, Prince Rupert's secretary, that "Prince Rupert is in very bad state and so bad that he do now yield to be trepanned. It seems, as Dr. Clarke also tells me, it is a clap [attack, J.D.R.] of the pox which he got about twelve years ago, and has eaten to his head and come through his scull, so that his scull must be opened, and there is great fear for him "(VI, 143). Trephining was performed on 2nd February by James Moulins, otherwise known as Molines, Moleyns, or Mullins, surgeon to St. Thomas's Hospital and afterwards surgeon in ordinary to Charles II and James II. The operation was carried out "without any pain, he not knowing when it was done. Having cut the outward table, as they call it, they found the inner all corrupted, so as it come out without any force ; and their fear is, that the whole inside of his head is corrupted like that, which do yet make them afeard of him ; but no ill accident appeared in the doing of the thing, but all with all imaginable success, 
as Sir Alexander Frazier did tell me himself, I asking him, who is very kind to me" (VI, 49). The results of the operation were most successful in spite of the gloomy prognosis of some of the doctors. On 6th February Pepys hears that " the Prince do still rest well by day and night, and out of pain, so as great hopes are concerned of him : though I did meet Dr. Clarke and Mr. Pierce, and they do say they believe he will not recover it, they supposing that his whole head within is eaten by this corruption which appeared in the piece of the inner table "' (VI, 155). Finally or less than two months after the operation Pepys "saw Prince Rupert abroad in the Vane-Room, pretty well as he used to be, only something appears to be under his periwigg or the crown of his head " (VI, 239). It may be added that Rupert outlived the operation by fifteen years, his death taking place at the age of sixty-four. The successful treatment of venereal disease in another courtier by a titled but unqualified person is illustrated by the case of Sir J. Minnes who told Pepys that when he was with the King as a doctor abroad he cured Sir John Denham after the disease had spread all over his face (IV, 203). In view of the promiscuous behaviour of Charles' II the possibility of his having contracted some venereal disease naturally suggests itself. There is however nothing in the Diary to support this view.

Besides the cases of venereal disease among the courtiers, examples of its prevalence in the upper and middle classes are furnished by Anthony Lowther and his wife, the daughter of Sir William Pen, who were treated by the " tubb"; Sir William Butler's clerk Gilsthrop, "who looks like a dying man with a consumption got, as it is believed, by the pox", (VII, 21) ; and Lacy, an eminent actor, of whom Sir Thomas Crew says, that "he lies a-dying of the pox, and yet has his whore by him, whom he will have to look on, he says, though he can do no more" (VII, 19). Reference to the high incidence of venereal disease among University men may be found in a letter to Dr. Arthur Charlett, Master of University College, Oxford, in which Pepys speaks of the youth of our nobility and gentry, " the choicest and once brightest ornament of our nation . . . . soon betrayed to the more gross, contagious and destructive pleasures waiting them "' (Tanner, 1926).

As regards the prevalence of venereal disease in the lower classes of society during the Restoration, it is possible that the practice of the City "prentices" of pulling down the "bawdy-houses" was a retaliation for infection acquired there (VII, 349, 351). Mr. Arthur Bryant, the eminent Pepys scholar, however, has kindly informed me that it is more probable that their action was the result of a popular Puritan reaction against the vicious display of the Court.

A remarkable example of an epidemic of what was probably gonorrhoea is mentioned by Pepys in the Rawlinson Collection (Bryant, 1938), which occurred in Tangier and originated in a girl of fourteen named Joyce, who infected 400 soldiers as well as the secretary to the Governor, the infamous Percy Kirk. This outbreak, which recalls a similar occurrence related by Casanova which I have described elsewhere (1917), even if as is probable it is somewhat exaggerated, at least exemplifies the high infectivity of juvenile prostitutes:

Numerous references are made in the Diary to the chief but by no means exclusive source of venereal infection constituted by the existence of prostitution in different parts of London, particularly Mulberry Gardens (VIII, 22)-which according to Wheatley was on the site of Buckingham Palace and Gardens-Drury Lane (IV, 383), the Russian House in Morefield (VII, 6), Whetstone Park in Holborn (VIII, 145), Bartholomew Fair (II, 86), Fleet Alley (III, 256) and Moorfields (VII, 349 et seq.). The brothels appear to have been the resort of Members of Parliament, as Charles II on 9th December, 1666 ordered that when their presence was required they should be sought for not only in the playhouses but also in the bawdy-houses (VI, 88).

The most notable member of this ancient profession mentioned by Pepys (VII, 161 ) is Nell Gwyn who made the following " very pretty" retort to Becky Marshall who had taxed her with being Lord Buckhurst's whore : "I was but one man's whore, though I was brought up in a bawdy-house to fill strong waters to the guests, and you are a whore to three or four though a Presbyterian's praying 
daughter." In this connexion reference may be made to McLaurin's suggestion that Nell Gwyn's sterility was due to salpingitis which was probably of a syphilitic nature in view of the fact that she developed hemiplegia at the comparatively early age of thirty-seven.

Other notorious prostitutes mentioned by Pepys are Lady Bennett (I, 228, VII, 32) and Damaris Page, "the greatest bawd of the Seamen"' (VII, 351).

\title{
REFERENCES
}

Bryant, A. (1935) Samuel Pepys. The Years of Peril, London.

- (1938) The Saviour of the Navy, London, p. 27.

Ellis, H. (1910) Studies in the Psychology of Sex, 6, 297.

James, R. R. (1923) Brit. J. Ophthal., 7, 231.

Jeanselme, E. (1931) Traité de la syphilis, Jeanselme, E., and Schulmann, E., Paris.

Jones, W. (1915) Lpool med.-chir. J., 35, 192.

Luys, G. (1921) Traité de la blennorhagie.

MacArthur, W. P. (1928) Irish J. med. Sci., 6th ser., p. 211.

MacLaurin, C. (1921) Med. J. Aust., 2, 395.

-- (1930) De Mortuis. Essays Historical and Medical, London.

Power, D'Arcy (1895) Lancet, 1, 1357.

- (1904) Ibid., 1, 1011.

- (1917) Occasional Papers of the Samuel Pepvs Club, 1, 78.

Rolleston, J. D. (1917) Urol. cutan, Rev., 21, 260.

- (1934) Brit. J. vener. Dis., 10, 147.

- (1941) Brit. J. Derm., 53, 183.

Tanner, J. R. (1926) Private Correspondence and Miscellaneous Papers of Samuel Pepys 1679-1703 in the Possession of T. Pepys Cockereli, London.

- (1929) Further Correspondence of Samuel Pepys 1662-1679. From the Family Papers in the Possession of T. Pepys Cockerell, London.

\section{OPHTHALMIA NEONATORUM}

\author{
By ERIC ASSINDER, M.D. \\ Director, Venereal Diseases Department, General Hospital, Birmingham; Pathologist, \\ Birmingham and Midland Eye Hospital
}

Ophthalmia neonatorum is a serious disease and in view of the rather vague ideas which some people have, it would seem necessary to state what the condition really is. The Ministry of Health Statutory Rules and Orders (1926) have defined it clearly so that there should be no doubt on the matter. The definition given is "Ophthalmia neonatorum means a purulent discharge from the eyes of an infant, commencing within twenty-one days from the date of its birth." It will be seen that no mention is made of the gonococcus or of any other infecting organism ; neither is the degree of the purulent discharge a matter for differentiation. A purulent discharge, however slight, occurring in a baby up to three weeks of age should be notified as ophthalmia neonatorum. I venture to state that this is not being done in many places.

\section{Notification fallacies}

- From time to time I look at the returns given in the medical press under the heading of Notifiable Diseases. For England and Wales the average number of cases of ophthalmia neonatorum each week seems to be well under 100 , and yet the average weekly number from Birmingham alone in 1942 was about twentythree cases. In fact, the cases notified from Birmingham, a city of a million inhabitants, accounted for nearly one-quarter of the total cases from the whole country. In my view it is idle to suggest that the condition is more prevalent in this city than it is elsewhere. In Birmingham the doctors and midwives are encouraged to notify these cases and to send them for diagnosis and treatment to a central depot. I contend that for this reason the number of cases notified is far greater than that from any other town in the country. Although I do not believe that the cases are more numerous now than they were fifteen years ago, it is interesting to note the rise in the number of notifications. 